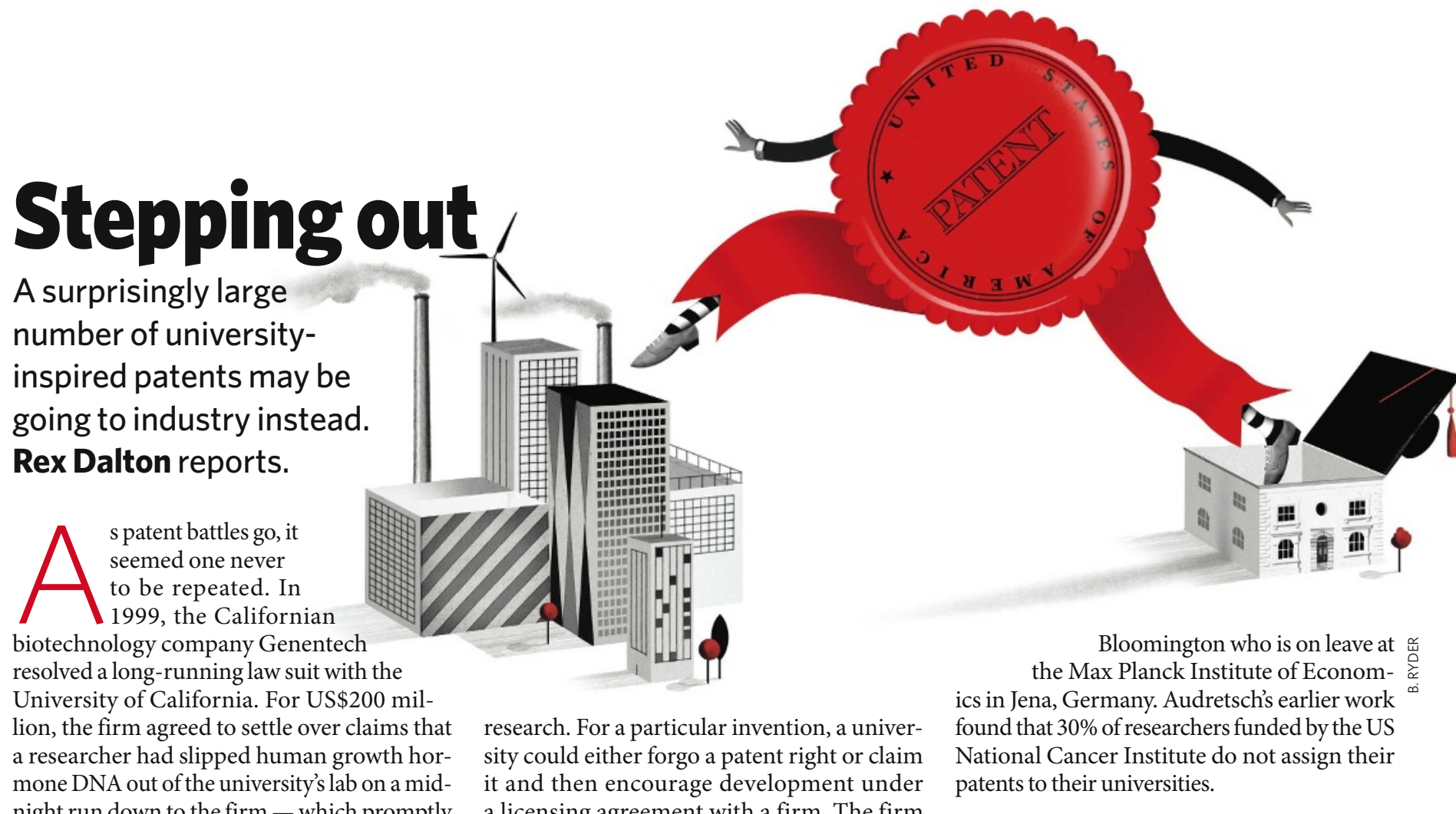

night run down to the firm - which promptly turned the material into its blockbuster drug Protropin (somatrem).

But such patent diversions may be more common than was thought, a study now suggests. A management researcher at the University of Georgia in Athens and his colleagues say that US universities are losing many of their researchers' inventions to industry. One-third of the patented discoveries made at universities were redirected to belong to private firms instead - and those taken away were the ones most highly cited in future patents, suggesting that they were the most valuable.

"This is largely a system failure - professors [are] systematically engaging in invention diversion into a black market, where industries patent them," says Gideon Markman, who led the team that published the findings (G. D. Markman, P. T. Gianiodis and P. H. Phan J. IEEE Trans. Eng. Manage. 55, 29-36; 2008).

\title{
Royal top-up
}

For universities, the financial stakes can be substantial. For instance, the 10-campus University of California system received $\$ 193.5$ million in fiscal year 2006 from patent royalties and fees. The absolute numbers may be small compared with overall institutional budgets - the state budget for the University of California that year was around $\$ 3.5$ billion - but the flow from patents is, in essence, free money for the universities at a time when funds are getting tight.

Markman is one of just a few scholars looking at how universities are faring in the wake of revolutionary changes in patenting academic research. In 1980, a law called the Bayh-Dole Act allowed US universities to start patenting inventions stemming from federally funded a licensing agreement with a firm. The firm would then pay royalties to the university and inventing professor. Technology-transfer offices sprang up to facilitate this new law.

But as researchers, their business partners and even universities can make fortunes off publicly funded discoveries, temptations to use the system for personal benefit have grown immensely. University executives, government officials and leaders of watchdog organizations often chatter about subversions: a lab animal making valuable protein might quietly disappear, or an engineering tool might shift from a professor's academic computer to his or her consulting business.

Markman and his team have been tracking what happens to this lost information. Their study focuses on 7,650 patented discoveries in biomedicine, information science and engineering made

"The technologytransfer concept is still in its infancy." - Michael Crow between 1989 and 2003 at 54 US universities. It shows that the more valuable the patent is, the more likely it is to be diverted to industry.

"I'm not surprised - that's consistent with my own thinking," says Michael Crow, president of Arizona State University in Tempe, which is itself trying to spin off an industrial cluster. "The technology-transfer concept is still in its infancy, and universities are still figuring out how to do things."

Administrators at technology-transfer offices are more sceptical. "I really question if one-third of the best inventions are leaking out the back door," says Jon Soderstrom, director of Yale University's technology-transfer office. "It seems awfully high to me - but it may be."

Data confirming Markman's results are expected in the near future from David Audret$\mathrm{sch}$, a researcher from Indiana University in Nature.

\section{Deal makers}

Others aren't so sure. A team from the Georgia Institute of Technology in Atlanta has published a study online in the National Bureau of Economic Research (J. Thursby, A. Fuller and M. Thursby www.nber.org/papers/w13256; 2007). The results showed that many discoveries that could be interpreted as being 'lost' in fact occurred when professors were doing outside consulting with industry that had been previously approved. The team found that $26 \%$ of 5,800 patents went solely to outside firms - a similar proportion to what Markman found but say that follow-up interviews suggest these numbers are due to acceptable outside consulting.

For his part, Markman says that professors who do the most consulting also divert the most technology. Once an academic has started working with an outside firm, he or she is in a better position to divert technology, Markman argues.

Markman plans to examine the diverted patents in case studies to determine exactly what happened to each. "It should be fascinating to see what we find," he says.

In the meantime, experts suggest simple ways to keep patents at the universities at which they were made. Step one is to break down all barriers between technology-transfer offices and faculty members, to ensure proper working relations. Step two is to maintain constant relationships with industry, intellectual-property attorneys and venture-capital firms.

Given the history of patent diversion, though, both steps may be harder than they seem.

Rex Dalton is a US west coast correspondent for 